\title{
Two ways to develop the company's innovation
}

\author{
Dominika Jagoda-Sobalak ${ }^{1}$, Iwona Lapuńka ${ }^{2}$ \\ ${ }^{1}$ University Opole University of Technology, Faculty of Production Engineering and Logistics, \\ Prószkowska 76 Street, 45-758 Opole \\ ${ }^{2}$ University Opole University of Technology, Faculty of Production Engineering and Logistics, \\ Prószkowska 76 Street, 45-758 Opole \\ d.jagoda@po.opole.pl,i.lapunka@po.opole.pl
}

Keywords: creativity, innovations, user-driven innovation, supply innovation

Abstract: This article indicates the need to create innovation in the economy. The article describes the process of designing and implementing innovative solutions using methods that support creative problem-solving and with using the concept of user driven innovation. The presented concepts are based on the analysis of the literature and on own research carried out. The article ends with conclusions and recommendations regarding broadly understood management, including the management of innovative potential developed on the basis of literature review and conducted research.

\section{Introduction}

Innovations, which reflect technological progress and modernity, are one of stimuli of the business competitiveness. Their diffusion to the sphere of business contributes largely to development of national economy. They are also treated as specific tools of entrepreneurship, which is expressed in constant search for new concepts of productive factors and is a driving force of the economic progress (Bessant, Pavitt, Tidd, 2006). Companies operating on a modern, dynamically developing market must be characterized by innovation, efficiency and flexibility of action.

Innovations occur in all phases of economic activity. Starting from design, through products, marketing activities, customer service, management, price determination to control (Eagar, Oene, Boulton, Roos, Dekeyser, 2011).

Innovations appearing in the company are closely related to gaining new knowledge about the market, competitors, clients, achievements of science and technology or financial and legal solutions (Drucker, 1995).

Efficient management of innovative activity can be based on the Hellriegel organizational change model, according to which objectives, employees, technologies, structure, strategies should be taken into account in business management. (Adair, 2007).

Innovation should be considered in a material or functional approach. In material perspective, it is perceived as a result of applying knowledge. In adopting innovations in the functional approach, in addition to the final result of the application of knowledge, the activities preceding the creation of a given result are also included (Bessant, Pavitt, Tidd, 2006).

Innovation can be classified in many ways due to: subject, source, scope of activity, etc. Particularly important in the design of innovation is the division based on the basis of their 
formation:

- innovations "hauled" by the market - demand-side innovations (Fig. 1). The most important role is played here by the demand factor. The use of this model is associated with marketing activities, conducting market research in order to direct R \& D development work.

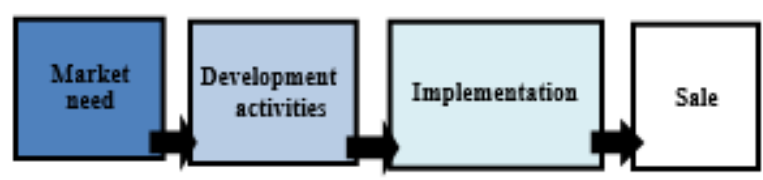

Figure 1: innovations "hauled" by the market - demand-side innovations (Rothwell R., Gardiner P., 1983)

- innovations "pushed" by science - supply-side innovations (Fig. 2) - the reason for their emergence consists in scientific achievements. An innovative company should therefore follow the development of scientific research and be characterized by R \& D activity.

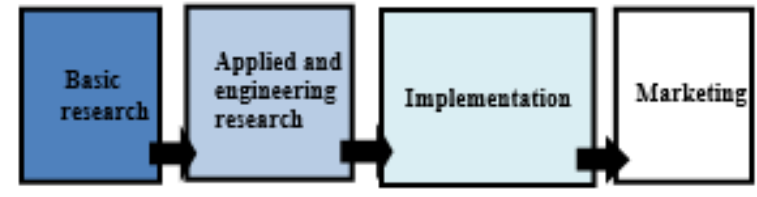

Figure 2: Innovations "pushed" by science - supply-side innovations (Rothwell R., Gardiner P., 1983)

The demand-side approach to creating innovation means the process of using the employees' knowledge by enterprises (users should be understood not only as individual clients, but also enterprises and institutions) and deriving financial benefits from it. Speaking of the knowledge of users, we mean primarily hidden knowledge, and therefore the one that was acquired as a result of experience, difficult to be recorded and passed on. In the demand-side approach to creating innovation, it is important to discover the hidden needs of consumers. They can express their ideas, concepts and design solutions, and thus be a source of innovation that may affect not only products, services, but also the organization of processes or technologies. The mentioned definition of the demand-side approach to innovation should emphasize two elements concerning the innovation process. First, the innovation process should be based on understanding of the actual needs of users, which are usually difficult to be defined and expressed by the users themselves. That is why enterprises applying the concept of demand-oriented approach to innovation must implement innovative processes, including increasingly perfect methods and tools (e.g. ethnographic methods) allowing for more precise, in contrast to traditional marketing methods, defining areas concealing new development opportunities for the company. Secondly, the innovation process should be undertaken with systematic (and therefore scheduled) participation of the users. That is why enterprises should take into account, already at the stage of establishing innovative strategies, the participation of users in the process of creating new products and using their hidden knowledge by directly integrating them into the work of a team that creates a new product. Among the new concepts related to the demand-oriented approach to innovation, one can distinguish those that have grown up in the fields of management and marketing as well as economic sciences. These are: the User-Driven Innovation concept and the concept of mass customization.

The supply-side approach enables creating radical innovations, standing out from the competition, using resources and strengths of the company. However, it requires research, creativity and a greater risk (as market needs have not been investigated in this case). This type of innovation supports organizational integration, the process of communication or increases the motivation of 
employees to generate ideas. It creates a creative work environment, a positive image of the company (as an innovator in the industry). However, it is not always easy to unleash the creative potential of employees. Therefore, the article presents concepts of creating innovation based on wakening, stimulation of creativity through the use of inventic methods and a tool to facilitate the application of these methods in the company.

\section{Supply innovation and creative organization}

Innovation has become one of the main economy elements based on the knowledge and it gains strategic importance in the context of generation economic growth, which in turn translates into society welfare. Already 20 years ago Drucker stated that the enterprise, which is not able to create innovation disappears (Drucker, 1995). According to experts, in contemporary world the growing pressure of competition causes that the ability to create innovation becomes one of key factors determining the developmental potential of companies. Among driving forces of innovation, there are listed desire to reduce costs and prices, increase expenditure on research and technology combined with intensive knowledge, interrelation of the sphere of science with industry, as well as commercialization of research results.

One of the ways to develop the innovative potential of an enterprise is to use the creativity of employees to create innovative solutions. Creativity management is a process the results of which are difficult to predict. It should be consistent with all management functions (with planning, motivating, organizing and controlling). Already at the recruitment stage one should evaluate the candidate's level of creativity, his or her creative abilities (it can be done through the application of specialist psychological tests). Creativity of employees should be developed through training, workshops and organizing creative sessions. There are a number of methods, including synectic and inventive ones, that develop creativity, mobilize the mind to look for unconventional solutions, facilitate the design of innovative concepts. Creativity management is also a motivation system focused on creativity, promoting creative attitudes. The motivating system should also be consistent with the culture of the organization, because these elements interpenetrate.

The article proposes ideas for managing and stimulating the creativity of employees by using the inventic methods for these processes.

nventic methods according to the CERMA classification (acronym of the French name of the Centre for Studies and Applied Methodologies - Center d'Etudes et Recherches en Méthodologie Appliquée) adapts to one of four stages: defining and identifying problems, gathering information and problem modelling, analysis and evaluation problem, finding solutions (Fig. 3).

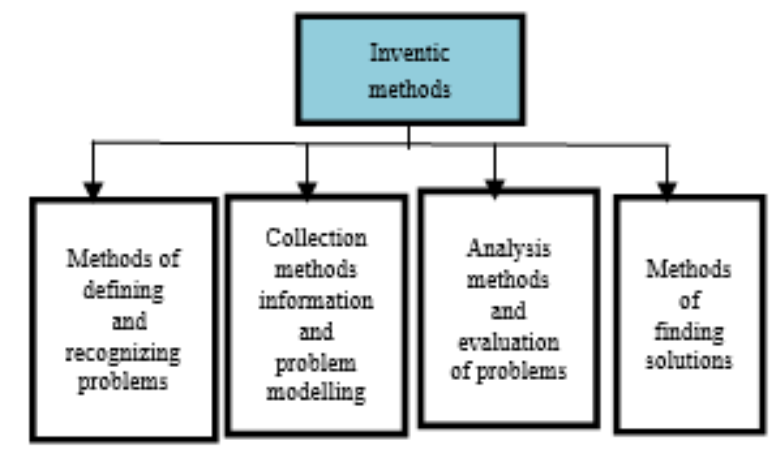

Figure 3 Division of the inventic methods according to CERMA (Martyniak, 1985)

The use of the inventic methods forces the renouncement of routine (blocking creativity and inhibiting innovation). Inventic methods also build community spirit in the team, improve communication, positively affect the atmosphere of work. 
However, there is a difficulty associated with the use of creative methods. Their poor description in literature, a small number of experts, or focusing exclusively on the psychological aspect of the methods discussed (and not on the results) make their use difficult in enterprises. Therefore, a simple tool for choosing methods for creative problem solving (in particular, in-house methods) for the company problems, was proposed. The tool is to provide information on how to apply the method in given conditions (situation) and provide it with an understandable, synthetic description, enabling its immediate application.

However, there is difficulty in applying creative methods. Their limited description the literature, small number of experts, or their focus on only the psychological aspect of discussed methods (rather than also on results), hinders their use in enterprises. Therefore, a simple tool for the selection of methods of creative problem solving was proposed (in particular inventic creation methods), with regard to problems of the enterprise. The tool (in the form of a database of inventic methods) is supposed to provide information, which method should be applied in the given conditions (situation), and provide a comprehensible, synthetic description that enables its immediate application.

Empirical studies included three stages:

1) Preliminary studies - creativity tests were conducted in enterprises, which enabled us to measure the creativity of employees in the given enterprise. Tests were drawn up based on specialist psychological tests. Tests enabled us to assign employees of the given enterprise to one of three groups: innovators, persons not fully using their creative abilities, and persons whose creativity is "dormant". Moreover, barriers limiting the individual and collective creativity were identified in surveyed enterprises using an in-depth interview.

2) Basic empirical research - in analysed enterprises, the employees participated in creative sessions in which inventic creative methods were used in order to design innovative solutions. An expert was responsible for the selection of methods and carrying out the creative session. Innovative organizational, procedural, product solutions were designed. Employees positively used the process of the creative sessions and the application of inventic creation methods to solve problems.

3) Development of a tool supporting the selection of inventic creative methods to the problem. Conclusions from conducted basic empirical research, preliminary studies, and literature analysis were used to build a tool supporting the selection of inventic creative methods to the problem (situation) of enterprises. One by one the base of inventic methods l was verified in enterprises. Verification was based on thd assumption that in the creative session there would be the use of methods indicated by the selection tool, the expert will only carry out an open observation.

It should be noted that currently there are longitudinal studies being conducted, and tests assessing the creativity level in enterprises after certainic time of applying inventic creation methods are repeated in order to study the changes of this level.

The design of the tool support the selection of the invent methods for the innovation design process took place in several stages:

The first design stage of the tool supporting selection of inventic creation methods was to determine the criteria for the selection of inventic creation methods to the problem

Criteria for selection of methods based on literature studies, preliminary and basic studies include:

- The number of participants in the creative session (individual or team). There are inventic creation methods, which require one to work in the group. There is also a group of methods, which can be applied to both individuals and to a group.

- Method area (comprehensive or fragmentary). This criterion is aimed to indicate, whether the method is supposed to be applied only to search for solutions or is supposed to be helpful in the entire problem-solving process (from defining the problem to seeking solutions). 
- Duration (up to $1 \mathrm{~h}$, up to 1 working days, above 1 day). This criterion is very important for entrepreneurs, because it enables to choose the method to time at its disposal.

- Method nature (based on forced or free associations, analytical methods; lists of test questions, not-systematized).

- Creativity and experience, this criterion is necessary to determine whether the organization's appointed team for creative problem solving is creative. The previously carried out test is supposed to be used for this purpose. It is possible also to be based on previous experience associated with application of inventic creation methods.

- Problem type (technical/technological, organization and management).

The design base of inventic methods supporting the selection of inventic creation methods to the problem in a form of a database of the inventic creation methods is unusually easy to use and transparent, which makes it easier to apply. From the main menu, it is possible to carry out one of four orders: browse the database of inventic creation methods, add a new method, select a method to a determined situation, or close the database. The most important element of the main menu and specific objective of the designed tool that supports the selection of inventic creation methods to the problem is to find a method that will be selected to the following factors: solving entity, duration of creative session, method nature, creativity, and experience in applying inventic creation methods to a problem type. While selecting the method we can define all criteria. The result of the selection will be shown in table. As a result of the defined criteria, the proposed methods will be indicated along with their description.

Design stages of database included:

1) Creating tables - 6 tables were created for the selected criteria and for the inventic creative methods.

2) Providing clear values in the table fields (keys) - keys were entered in tables: Id_metody, Id_podmiot, Id_obszar, Id_charakter, Id_rodzj, Id_czas, Id_kret_dosw.

3) Determining the relation between tables - determined the correct connection of related data in a logical whole.

4) Creating the form -5 associated and 6 supporting forms were created for communication with the user.

5) Creating queries - in order to enable searching (selecting) methods and displaying search results.

6) Creating reports - created reports display inventic creation methods (that meet the criteria) along with their characteristics and description.

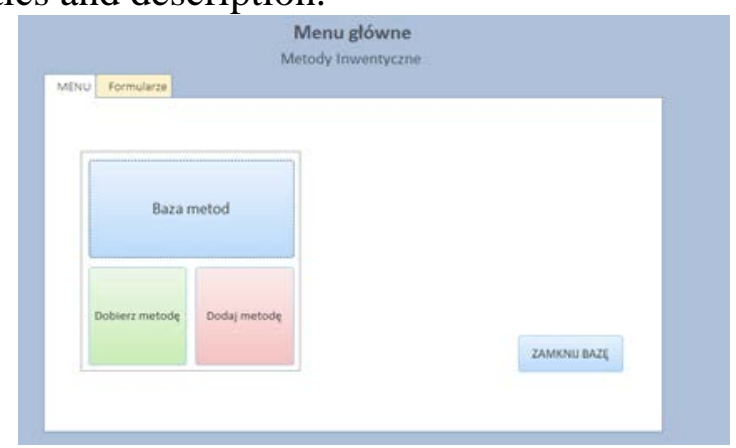

Figure 4 The main menu of the base of inventic methods.

Research in a form of a repeated case study indicated that inventic creation methods support the growth of innovation. They enabled to generate innovative solutions: processes, products and organisational innovation. Positive opinions of the employees in relation to creative sessions with inventic creation methods confirmed the benefits from applying inventic creative methods. The 
conducted studies enabled to build the creative organization, identification, and development of the creativity level of employees, and eliminated barriers limiting their creativity. The applied inventic creation methods extorted on employees a creative way of thinking, and taking brave, unconventional decisions, contributed to integration of employees, created the climate that supports creation of new solutions, which in consequence significantly affected the creativity in individual enterprises.

The designed tool enables to popularize inventic creation methods, and their application without participation of the experts. The process of tool verification has proven the correctness of the criteria selection and assumptions.

The basis of innovative enterprise development is the economy of creativity. An organization that eagerly leads to innovation should focus on the elements that support the creativity of the individuals and the entire organization. Therefore, it is necessary to supplement the company's orientation and culture with the creative ability of the organization, which is the main carrier of innovation, competitiveness or even survival. Creative strategic decisions and unconventional activities are to serve the mutual development of the enterprise and the environment. The proposed concept of creating innovative solutions using the inventic methods is a response to contemporary business challenges.

The supply-side approach to creating innovation is usually time-consuming, costly and more risky. Therefore, it is reasonable to support the process of designing and implementing innovations by the inventic methods the main purpose of which is to use the creativity wporkers employed in the company (own resource) to shorten and intensify thought processes (time shortening) and stimulate creativity (overcoming barriers limiting it) as well as more objective look at the proposed solutions.

The approach to creating innovation (demand-side or supply-side) depends on the situation of the company, the characteristics of the customer, industry or the entire market. It is important that enterprises consciously choose the best option at a given time and are able to properly carry out the process of designing and implementing innovations.

\section{User-driven innovation as a key factor for the}

In the industrial society the technology-driven innovation dominated the development. Traditionally innovation has been technology driven. But throughout the 20th century the technological management got more important and educational institutions and science centers which supported the technology-driven innovation were established. Now, it's not necessarily this type of innovation that leads to the largest profit. It's not only a competition to discover new technology anymore, but also customer understanding and the perception of user needs (Rosted, 2005; Nordic Innovation Centre, 2007). According to Roberto Verganti (2009), the framework to depict types of product strategies is very simple - we look for changes in technology and meaning (Fig. 5). The companies that are repeatedly the most successful in the marketplace with their new product developments are those that proactively adhere to do more than just answer the market needs. This could be changing the way how people use the product or service, creation of network externalities e.g. growing an ecosystem or centering user within the product meaning. 


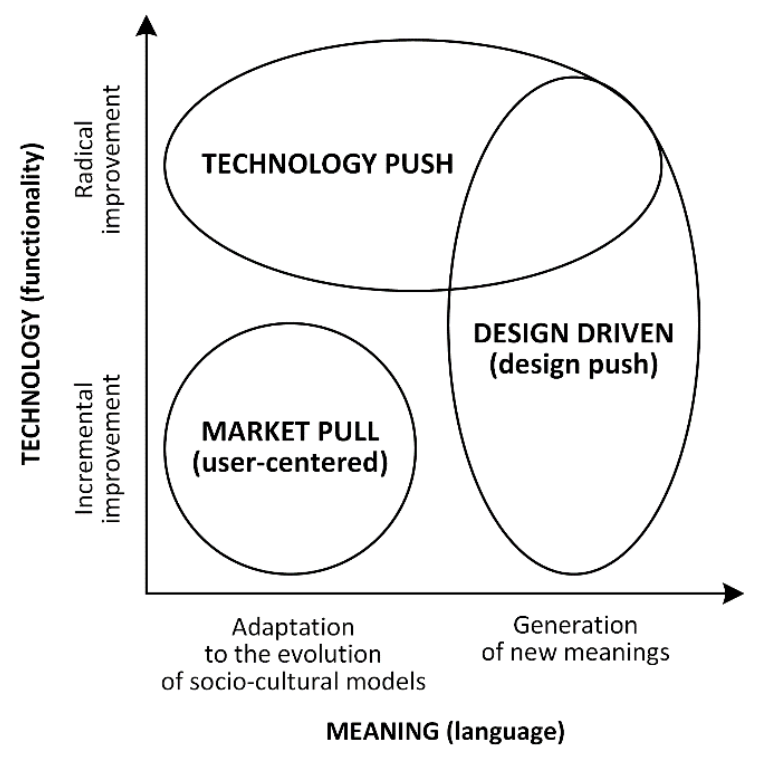

Figure 5 Innovation strategies (Verganti, 2009)

New trends in innovativeness pertain both to creating goods and services (research and development - R\&D, user-driven innovation), and to the changes within the structure of a company (organizational and marketing innovation). New forms of innovation (non-technological, userdriven, open, and social) require business entities to display new skills as well as to conduct an active policy that will stimulate the creation of such innovations in companies.

Particularly worth noting are the benefits of user-driven innovation (UDI). Progressing globalization processes have a direct impact on the increasing importance of consumers, understood not only as purchasers, but also as co-creators of goods and services. As a result, production and services are better suited to the expectations of the end user, while at the same time the costs of innovation are reduced. UDI is a method of implementing innovation focused on creating new ideas and solutions based on consumers' knowledge and needs. In other methods of implementing innovation, the consumers' knowledge is used mainly to assess existing solutions.

User-driven innovation is based on a more thorough understanding of both the explicit and implicit needs of consumers, their expectations and requirements. It consists in acquiring and using information, ideas and ready-made solutions proposed by consumers. User-driven innovation is poised to become the second pillar of programs supporting innovative businesses, alongside technological innovation. In general, there are two main perspectives on user-driven innovation: the voice of the customer perspective, and the lead-user innovation perspective (cf. table 1). These two 'schools of thought' are borne out of the academic research and practical experiences of David Kelley, Tim Brown and Eric von Hippel (among many others) (Nordic Council of Ministers, 2006).

It is assumed that business activity of companies in the scope of $\mathrm{R} \& \mathrm{D}$ with active cooperation on the part of consumers (user-driven innovation) can be treated as a specific innovation project serving the effective execution of strategic business goals of a company. Initiated in the scope of $\mathrm{R} \& \mathrm{D}$, gradually laid out and expanded in terms of results, such a project requires project-oriented management. The management model for $R \& D$ processes is reflected in project management methodologies. Classical methodological approaches reflect the philosophy and organization of project processes in the form of waterfall models, driven by the principle 'plan first to avoid change'. In the waterfall model, it is assumed that precisely defined stages follow in succession, always in the same order. In R\&D processes, this is possible when actions are executed in the scope of fundamental and applied research. The strategy of implementing solutions within such a model is currently termed market-push strategy. 
Table 1 Comparison between traditional and user-driven approach to innovation

\begin{tabular}{|c|c|c|c|c|c|}
\hline \multirow[b]{2}{*}{$\begin{array}{l}\text { Aim of the } \\
\text { process }\end{array}$} & \multirow[b]{2}{*}{$\begin{array}{c}\text { 'Traditional' } \\
\text { product } \\
\text { development } \\
\text { and } \\
\text { marketing } \\
\text { methods } \\
\text { Identify } \\
\text { consumer needs }\end{array}$} & \multicolumn{4}{|c|}{ User-driven innovation methods } \\
\hline & & \multicolumn{2}{|c|}{$\begin{array}{l}\text { Voice of the customer } \\
\text { (design thinking) methods } \\
\text { Identify consumer needs }\end{array}$} & \multicolumn{2}{|c|}{$\begin{array}{l}\text { Lead-user methods } \\
\text { Identify solutions }\end{array}$} \\
\hline $\begin{array}{c}\text { Where } \\
\text { innovation } \\
\text { takes place }\end{array}$ & In the company & \multicolumn{2}{|c|}{$\begin{array}{c}\text { In the company } \\
\text { (often with external/consulting support) }\end{array}$} & \multicolumn{2}{|c|}{ Outside of the company } \\
\hline $\begin{array}{l}\text { Method/ } \\
\text { process }\end{array}$ & $\begin{array}{l}\text { - segmentation, } \\
\text { statistics and } \\
\text { surveys } \\
\text { (asking } \\
\text { consumers } \\
\text { what they } \\
\text { need), } \\
\text { - prototypes, } \\
\text { - test groups }\end{array}$ & \begin{tabular}{|l} 
Product-focused \\
- observation \\
(discovering \\
consumers \\
identified and \\
latent needs), \\
- brainstorming to \\
define consumer \\
needs, \\
- multiple alternative \\
prototypes/solution \\
s, \\
- reiterative testing \\
and implementation
\end{tabular} & 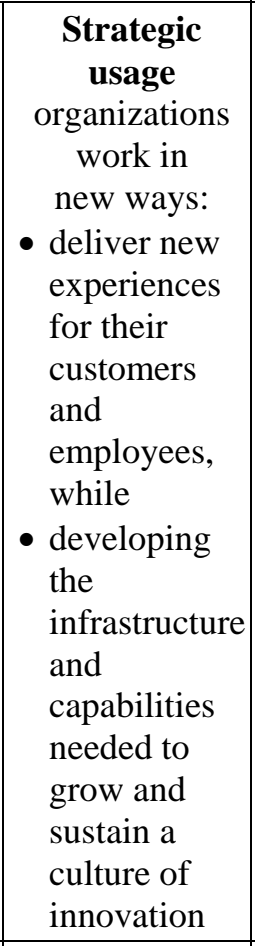 & $\begin{array}{l}\text { Co-invetion, } \\
\text { mass } \\
\text { customization } \\
\text { - company } \\
\text { develops } \\
\text { product/service } \\
\text { 'platform', } \\
\text { - company } \\
\text { develops } \\
\text { toolkits and } \\
\text { provides to } \\
\text { users (with } \\
\text { open access), } \\
\text { or } \\
\text { - company } \\
\text { initiates an } \\
\text { open process } \\
\text { for users to } \\
\text { propose } \\
\text { solutions }\end{array}$ & $\begin{array}{l}\begin{array}{c}\text { Lead-user } \\
\text { drives }\end{array} \\
\text { innovation } \\
\text { - Either lead- } \\
\text { users do the } \\
\text { prototyping } \\
\text { and testing } \\
\text { spontaneously, } \\
\text { or } \\
\text { - companies } \\
\text { identify lead- } \\
\text { users } \\
\text { (searching } \\
\text { different } \\
\text { domains), } \\
\text { - lead-user } \\
\text { networks } \\
\text { create and test } \\
\text { solutions }\end{array}$ \\
\hline Case example & & P\&G, HP & Intel, Electrolux & Adidas, Lego & Microsoft, 3M \\
\hline Comment & & \multicolumn{2}{|c|}{$\begin{array}{l}\text { - higher innovation 'hit rate' } \\
\text { - faster and less expensive than } \\
\text { traditional innovation methods } \\
\text { (although not yet 'scientifically' } \\
\text { proven), } \\
\text { - (strategic usage) requires new skill } \\
\text { sets, shifts in resources and } \\
\text { investment in organizational } \\
\text { changes }\end{array}$} & \multicolumn{2}{|c|}{$\begin{array}{l}\text { - high innovation 'hit rate' (as } \\
\text { commericalizing solutions } \\
\text { developed by lead users } \\
\text { themselves), } \\
\text { - fast and inexpensive innovation } \\
\text { process, } \\
\text { - requires investment in } \\
\text { identifying lead users in own } \\
\text { and related customer bases, } \\
\text { - 'democratizing innovation’ } \\
\text { means that the company partner } \\
\text { with users and needs to accept } \\
\text { relinquishing control }\end{array}$} \\
\hline
\end{tabular}

Source: (Nordic Council of Ministers, 2006)

Developmental works, on the other hand, based on information processing so as to adjust the developmental process to the changing environment (e.g., target market for developed goods and 
services), necessitate an agile and adaptive approach to management. They are driven by a different principle - 'implement incrementally to manage change'. Efficiency, flexibility and rapid pace are among the most significant features of the agile approach to user-driven innovation (Abbas, Gravell, Wills, 2008). These result from self-organization, adaptability, radical shortening of the development cycle, the introduction of control events ensuring the high incidence of customer or end user feedback, as well as other elements comprising the internal and external project environment.

The unpredictable and unique nature of innovation projects in $R \& D$ is a consequence of the market-pull strategy. Innovation projects are characterized by an element of uncertainty as to the course of the project and thus to its future result. As a general rule, at the outset of such projects, only the general aim is known, while the exact course of action is adjusted on the fly, in close cooperation with users/consumers.

\section{Conclusions}

Innovation has become one of the major elements of knowledge-based economy and keeps acquiring strategic importance in the context of generating economic growth, which translates into social prosperity. Up to a quarter of a century ago, Drucker (1995) already stated that 'a company unable to create innovation dies'. According to experts, due to the increasing pressure of competition in the modern world, the ability to create innovation becomes one of the key factors determining the developmental potential of companies. Customers and consumers increasingly often take part in creating innovation. The most modern of currently known innovation implementation methods, oriented at creating innovative solutions based on consumers' needs, is user-driven innovation or UDI. Simultaneously, the need to include the project approach in the creation of innovative solutions is acknowledged.

Improving the innovation process does not necessarily involve designing completely new formulas. It is possible to re-use the solutions that are employed and perform well in project execution. Rather, it is the tools and methods for aiding creative processes that require integration with project processes, so as to comprise a coherent system which will play a pivotal role in increasing the effectiveness of conducting innovation projects. In recent years, the project approach has become an increasingly popular tool for achieving operational and strategic goals and to generally advance the business activity of organizations in fields such as innovation management. Integration of the project approach with innovative processes should allow expedient execution of business strategies in contemporary companies.

User-driven innovation implies that businesses constantly strive to deliver a product to provide consumers with a special value offer or experience, which is completely different from the competition. This perspective forces businesses to a profound understanding of customer needs as well as the ability to translate it into products, services or experiences that are unique (Rosted, 2005; Bar, Riis, 2000). It is characterized by the systematic scientific mapping of consumer needs and the company's capacity to transform it into goods (Paiva, Domingues, Pinto de Andrade, 2016). The focus on, and devotion to user-driven innovation is today very varied among the different countries.

Innovations based on systematic and scientific methods of revealing the users acknowledged and not-acknowledged needs are more accurate, and have a greater chance of achieving commercial success and increased customer satisfaction. This kind of innovation process is an interdisciplinary field which gathers new methods and different knowledge and tools from social sciences like psychology, anthropology and ethnology to get a deeper understanding of the costumers' experience and latent demands. People should be educated in the ability to innovate based on the needs of real people, and not on how things are seen or done within a particular company tradition. 
This holistic approach to innovation can be used in any industry and in any business.

\section{References}

[1] Abbas N., Gravell A.M., Wills G.B. 2008. Historical roots of agile methods: where did 'agile thinking' come from? Agile Processes in Software Engineering and Extreme Programming, Lecture Notes in Business Information Processing, 9, pp.94-103.

[2] Adair J. 2007. Leadership for Innovation. Kogan Page Limited. London.

[3] Bar F., Riis A.M. 2000. Tapping user-driven innovation: a new rationale for universal service, Information Society, 16 (2), pp.99-108.

[4] Bessant J., Pavitt K., Tidd J. 2006. Managing Innovation - Integrating. Technological, Market and Organizational Change. Wiley and Sonns, Hboken.

[5] Drucker P. 1995. Innovation and Entrepreneurship: Practice and Principles. Polskie Wydawnictwo Ekonomiczne. Warszawa.

[6] Eagar R., Oene F., Boulton C., Roos D., Dekeyser C. 2011. The Future of Innovation Management: Thr Next 10 Years. $A D L$.

[7] Nordic Innovation Centre 2007. User-driven innovation. When the user makes the difference. Norwegian University of Science And Technology, Trondheim.

[8] Paiva T., Domingues C., Pinto de Andrade L. 2016. Innovation and knowledge transference in a cluster userdriven innovation perspective - the Inovcluster experience. International Journal of Food Studies IJFS, No.5, pp. 54-60. [9] Rosted J. 2005. User-driven innovation. Results and recommendations. Fora. Copenhagen

[10] Rothwell R., Gardiner P. 1993. The role of the Design in Product and Process Change, Design Studiem, nr 3, pp.161-170.

[11] Verganti R. 2009. Design-driven innovation: changing the rules of competition by radically innovating what things mean. Harvard Business Press. Boston, MA. 